\title{
Citric Acid Extraction in Citrus hystrix Peels as an Alternative Material for Reducing Water Hardness
}

\author{
*Ni Nyoman Suciani, Irwan Said \& Anang W. M. Diah \\ Pendidikan Kimia/FKIP - Universitas Tadulako, Palu - Indonesia 94119 \\ Received 18 December 2020, Revised 22 january 2021, Accepted 22 February 2021 \\ doi: 10.22487/j24775185.2021.v10.i1.pp53-58
}

\begin{abstract}
Water hardness will have a destructive impact if consumed in a long time. Hard water contains high calcium contents, including inorganic calcium. The accumulation of calcium in the body at a specific time causing kidney stones, and some will settle in the blood that causing calcification which can be fatal to health. An alternative is needed to reduce the level of water hardness. This study aimed to determine the effect of using citric acid on citrus hystrix peels on water hardness. Citric acid was obtained through the maceration extraction method from citrus hystrix. The citric acid extract was made into several concentrations of 50,100, and $150 \mathrm{ppm}$ then added to hard water. Determination of decreased total water hardness after adding citric acid used method complexometry titration. The results of the analysis show that citric acid is able to reduce water hardness of the sample water from Palu city area.
\end{abstract}

Keywords: Water hardness, citrus hystrix, citric acid, maceration, complexometry

\section{Introduction}

In terms of quality, water must be available in conditions that meet health requirements. Water quality can be analyzed from three parameters, namely physical, chemical, and biological parameters. Chemical parameters include DO (dissolved oxygen), BOD (biological oxygen demand), COD (chemical oxygen demand), $\mathrm{pH}$, salinity, conductivity, hardness, nitrate, and nitrite (Kusnaedi, 2010).

Palu City is an area that has high groundwater hardness (Labanu et al., 2015). If the water is heated, you will see white deposits sticking to the bottom of the pot or pan. When the tap water is used for cooking, for example, washing vegetables or rice, the water will have a small amount of sediment which will be consumed when consumed. The longer the residue increases and causes diseases that can endanger the health.

The maximum level of hardness allowed is $150 \mathrm{mg} / \mathrm{L}$; if the hardness is above $500 \mathrm{mg} / \mathrm{L}$ and consumed continuously, it will damage the human kidneys (Joko, 2010). Hard water contains high levels of calcium. If inorganic calcium is consumed, it will be immediately excreted through the secretory system, and some will settle in the kidneys. At a particular time, the accumulation of calcium in the body will cause kidney stones, and part of it will drop in the blood, causing calcification which can be fatal to health (Gomes, 1996). In general, hardness is caused by the presence of 2-valent metals or cations, such as $\mathrm{Fe}, \mathrm{Sr}, \mathrm{Mn}, \mathrm{Ca}$, and $\mathrm{Mg}$, but the main causes of hardness are calcium $(\mathrm{Ca})$ and magnesium (Mg) (Marsidi, 2001).

One alternative to reduce the hardness level of water is to use a metal ion chelating material. Kaffir lime is thought to reduce water hardness due to the content of citric acid, which can chelate metal ions (Munawaroh \& Handayani, 2010). Kaffir lime fruit, in its intact state, can last for a period of about two weeks (Srisukh et al., 2012).

In addition to citric acid, the active compounds contained in kaffir lime are flavonoids, glycosides, saponins, coumarin, amino acids, bergamottin, oxypeucedanin, and essential oils (Butryee et al., 2009).

According to Butryee et al. (2009), the acidity of citric acid is obtained from three carboxyl groups - $\mathrm{COOH}$, which releases protons in a buffer solution to control the $\mathrm{pH}$ of the solution. Citrate ion can react with many metal ions with chelating, so it is used as a preservative and water hardness remover (Harsanti, 2010). Citric acid is corrosive to many metals such as iron, magnesium, zinc, and cadmium, which form hydrogen gas and citrate salts (called metal citrates) (Ahmad et al., 2014).

In the food industry, citric acid is used as a flavor enhancer, inverting sucrose, producing dark color and chelating metal ions, while in the pharmaceutical industry, citric acid is used as a solvent and aroma generator, and in the cosmetic industry, it is used as an antioxidant (Bizri \& Wahem, 1994). 
Citric acid has four pairs of free electrons in its molecule, namely the carboxylic group, which can be assigned to metal ions, causing the formation of complex ions that are readily soluble in water (Setiawan et al., 2012).

The aim of the present paper is to examine the components contained in kaffir lime peel (Citrus hystrix), it can be assumed that orange peel can be used to reduce water hardness.

\section{Methods}

The tools used are oven, balance, funnel, beaker, scissors/cutter, blender, sample container (ceramic bowl), rotary evaporator, porcelain cup, measuring cup, measuring flask, burette, beaker, stirring rod, spatula, clamp. and statif, erlenmeyer flask and sample vials.

The materials used in this study were lime peel (Citrus hystrix), water samples from the Tondo and Tipo villages, filter paper, $96 \%$ ethanol, 0.001 $\mathrm{M} \mathrm{CaCO}_{3}$ solution, $1 \mathrm{~N} \mathrm{NaOH}$ solution, distilled water, tissue, rubber bands, ammonia buffered solution $\mathrm{pH}$ 10, Erichrome Black T (EBT), murexide indicator, EDTA standard solution 0.01 M.

\section{Lime Peel Preparation}

The lime, which is still green, is cleaned first, then the kaffir lime peel is separated from the pulp. Furthermore, the orange peel is washed using distilled water. The washed orange peel is cut into smaller pieces and oven-dried for 12 hours at $40{ }^{\circ} \mathrm{C}$. After the orange peel is dry, then mashed using a blender (Pratiwi et al., 2015)

\section{Extraction Process}

The orange peel sample was weighed as much as 50 grams and put into a $300 \mathrm{~mL}$ beaker. Then the sample was added with $250 \mathrm{~mL}$ of $96 \%$ ethanol and covered with aluminum foil, and then let stand for four days. After that, the mixture was filtered, and the filtrate was evaporated using a rotary evaporator for 35 minutes at $60{ }^{\circ} \mathrm{C}$. The resulting extract is stored in a porcelain dish (Pratiwi et al., 2015).

\section{Citric Acid Extract Solution Process}

Preparation of 50,100, and $150 \mathrm{ppm}$ citric acid extract, was performed by taking $2.5,5$, and 7.5 $\mathrm{mL}$ of citric acid, then put into a $100 \mathrm{~mL}$ volumetric flask and add distilled water until the limit mark.

\section{Determination of Citric Acid Levels in Extracts}

The extract of citric acid was taken as much as $10 \mathrm{~mL}$ and then put into $250 \mathrm{~mL}$ Erlenmeyer.
Furthermore, the citric acid extract was added with distilled water until the volume became $20 \mathrm{~mL}$ and added with three drops of phenolphthalein indicator. After that, the solution was titrated with $0.1 \mathrm{~N} \mathrm{NaOH}$ until the color changed (Haq et al., 2010).

\section{Standardization of EDTA Solution with $\mathrm{CaCO}_{3}$}

The standard solution of $\mathrm{CaCO}_{3}$ was taken as much as $25.0 \mathrm{~mL}$ and then put into a $250 \mathrm{~mL}$ Erlenmeyer. The standard solution is then added to $1.0 \mathrm{~mL}$ of a standard solution of $\mathrm{pH} 10$ buffer and 2-3 drops of EBT indicator. The solution will turn pink. The solution in the Erlenmeyer is then titrated with the prepared EDTA solution until the color changes from pink to blue. The experiment was repeated three times, and then calculated the molarity of the EDTA solution (SNI, 2004).

\section{Determination of Total Hardness}

A total of $100 \mathrm{~mL}$ of water sample was added to $2 \mathrm{~mL}$ of citric acid extract for each concentration. $50 \mathrm{~mL}$ of water sample was taken and put into Erlenmeyer. The water sample is then added to 1-2 mL of ammonia buffer solution. Then the solution is added with a bit of Eriochrome Black $T$ indicator until pink color is formed. The solution was then titrated with $0.01 \mathrm{M}$ EDTA solution until a blue color was formed. The treatment was repeated two times.

\section{Determination of Calcium Levels}

$100 \mathrm{~mL}$ of the water sample were added to $2 \mathrm{~mL}$ of citric acid extract for each concentration. $50 \mathrm{~mL}$ of water sample was taken and put into Erlenmeyer. The water sample was then added with $10 \mathrm{~mL}$ of $1 \mathrm{~N} \mathrm{NaOH}$ solution. Then the solution was sprinkled with a bit of murexide indicator until a pink color was formed. The solution was then titrated with $0.01 \mathrm{M}$ EDTA solution until a purple color was formed. The treatment was repeated two times.

\section{Results and Discussion}

\section{Determination of Total Hardness}

The total hardness of Tondo water, which is $140 \mathrm{mg} / \mathrm{L}$, indicates that Tondo water has a moderate hardness level. This is consistent with the statement of Marsidi (2001), which states that the water hardness level is $75-150 \mathrm{mg} / \mathrm{L} \mathrm{CaCO}$.

A decrease in the total hardness of Tondo water and Tipo water can be seen in Figure 1 . 


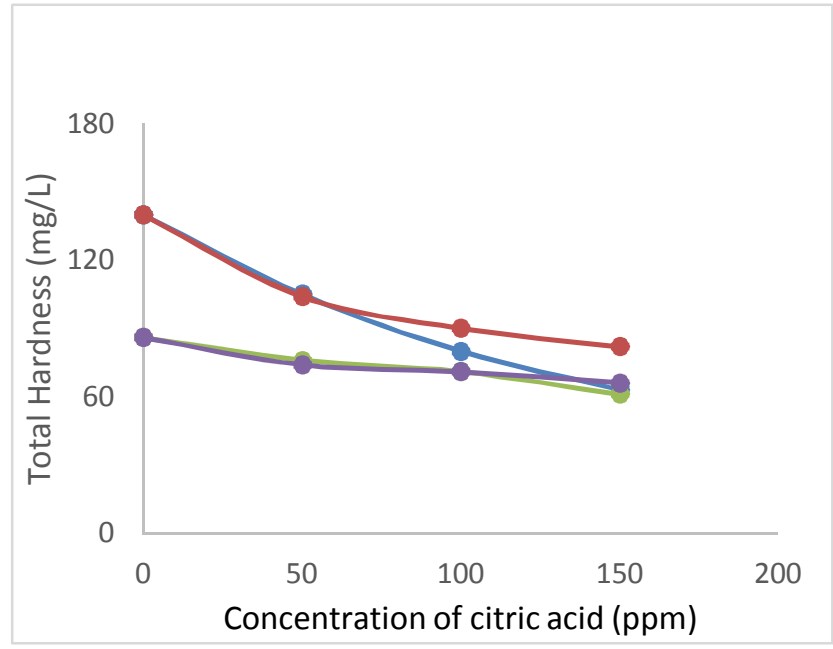

Figure 1. Water hardness level in the tondo and tipo areas ( $\bullet$ is commercial citric acid-Tondo; $\bullet$ is a citric acid extract-Tondo; $\bullet$ is commercial citric acid-Tipo; $\bullet$ is commercial citric acid extract-Tipo).

The addition of citric acid, both commercial citric acid and extracted citric acid, caused a decrease in the total hardness level. The increasing the concentration of citric acid added to the water, the more metal ions are bound to the citric acid. This is in accordance with the results of research by Chen et al. (2003), namely that by increasing the concentration of citric acid as a gel, more metal complexes are formed. The reaction mechanism that occurs is (Septiana et al., 2013):

$$
L^{+}+S^{-}=L S
$$

where $\mathrm{L}=$ Metal; $S=$ Chelating Compound; LS = Metal-chelating compound complex.

The results obtained showed a significant difference between the reduction in total hardness using commercial citric acid and the decrease in citric acid using extracted citric acid. Most likely, this can happen because there are other compounds that are dissolved in the concentrated extract obtained. The citric acid content obtained was $134.4 \mathrm{~g} / \mathrm{L}$. In addition, it is difficult to observe color changes, so that it affects the determination of the endpoint of the titration. The citric acid extract has a dark yellow color so that when it is added to the water sample, it causes the water sample to be bright yellow. When water is added with the Eriochrome Black $\mathrm{T}$ indicator, it produces an orange color.

Mining materials in the form of stones, gravel, and sand are widely available in the Tondo Village area. Apart from the minerals, there are also granite rocks in the Tondo Village, which are igneous rocks in situ. Granite is an igneous rock in a holocrystalline, feneritic, coarse-grained texture and contains minerals such as $4-10 \%$ quartz $\left(\mathrm{SiO}_{2}\right)$, 30-60\% Feldspar calcium $\left(\mathrm{CaAl}_{2} \mathrm{Si}_{3} \mathrm{O}_{3}\right)$, sodium plagioclase $\left(\mathrm{NaAlSi}_{3} \mathrm{O}_{8}\right.$ ) as much as $0-30 \%$, biotite $\left(\mathrm{K}(\mathrm{Mg}, \mathrm{Fe})_{3}\left(\mathrm{AlSi}_{3} \mathrm{O}_{10}\right)(\mathrm{F}, \mathrm{OH})_{2}\right.$ and hornblenda as much as 30-10\% (Ngadenin et al., 2014). The soil of the Tondo village area also contains gypsum, which has components in the form of $\mathrm{Fe}_{2} \mathrm{O}_{3}, \mathrm{MnO}$,
$\mathrm{Na}_{2} \mathrm{O}, \mathrm{K}_{2} \mathrm{O}, \mathrm{SO}_{3}, \mathrm{SiO}_{2}, \mathrm{CaO}, \mathrm{MgO}$, and $\mathrm{Al}_{2} \mathrm{O}_{3}$ (Siregar, 2010). The mineral content in these rocks is one of the factors that influence the high water hardness in the Tondo village area.

Water hardness mostly comes from its contact with the soil and the rocks that make up the soil. The high water hardness in the Tondo area is thought to be due to the rock content in the soil, which contains a lot of 2 valent metals. So that when the water passes through the rock, some metals will also dissolve into the water and cause the water hardness to increase.

Citric acid has a $-\mathrm{COOH}$ group that will bind metal ions when conditioned at $\mathrm{pH} 10$. So, in addition to making the Eriochrome Black $\mathrm{T}$ indicator work well, the addition of $\mathrm{pH} 10$ buffer solution also aims to maximize the work of citric acid to bind metal ions is in the water. This is in accordance with the opinion of Herjuna (2011), which states that increasing $\mathrm{pH}$ will cause the hydrogen bonds in the - $\mathrm{COOH}$ group to weaken so that the aggregates will separate from each other. Thus it can be stated that a relatively high $\mathrm{pH}$ will increase the concentration of -COO- which can function as a ligand.

The total hardness obtained in the Tondo area and the Tipo area water has a significant difference. This difference occurs presumably due to differences in land topography and the types of rocks that make up the land in the area. The geological condition of the city of Palu in general for all sub-districts is that it has Alluvial soil types. The geological soil formation in the city of Palu consists of volcanic rock and breakthrough rock that does not freeze. Besides that, there are also metamorphosed and sedimentary rocks. This is in accordance with the statement of Sutrisno \& Suciastuti (2010), which states that hardness in water mostly comes from contact with soil and rock formation. Generally, hard water comes from areas where the topsoil is thick and limestone is formed.

The area of Tipo Village has Granite, Sekis, 
several metamorphic rocks, and conglomerate rocks such as sandstone, mudstone, limestone, and marl $\left(\mathrm{CaCO}_{3}\right)$. Sandstone has a mineral composition, namely quartz $\left(\mathrm{SiO}_{2}\right)$, feldspar $\left(\mathrm{M}(\mathrm{AlSi})_{3} \mathrm{O}_{8}, \mathrm{M}=\mathrm{K}\right.$, $\mathrm{Na}, \mathrm{Ca}, \mathrm{Ba}, \mathrm{Rb}, \mathrm{Sr}, \mathrm{Fe})$, calcite, mica $(\mathrm{K}, \mathrm{Na}, \mathrm{Ca})$ $(\mathrm{Mg}, \mathrm{Fe}, \mathrm{Li}, \mathrm{Al})$ 2-3 (Al, Si) ${ }_{4} \mathrm{O}_{2}(\mathrm{OH}, \mathrm{F})_{2}$, glauconite, iron oxide, zircon, monazite and rutile Limestone-coral has the main content, namely the mineral calcium carbonate $\left(\mathrm{CaCO}_{3}\right)$ which occurs due to chemical and organic processes (Apriliani et al., 2012).

The total hardness level obtained in previous studies, namely research conducted by Labanu et al. (2015), was $98.58 \mathrm{mg} / \mathrm{L}$. The results obtained were different from the hardness level obtained in this study, which was $86 \mathrm{mg} / \mathrm{L}$. This happened presumably due to differences in the location of the water sampling used in the study.

\section{Determination of Calcium Levels}

The decrease in the total hardness levels of Tondo water and Tipo water can be seen in Figure 2 .

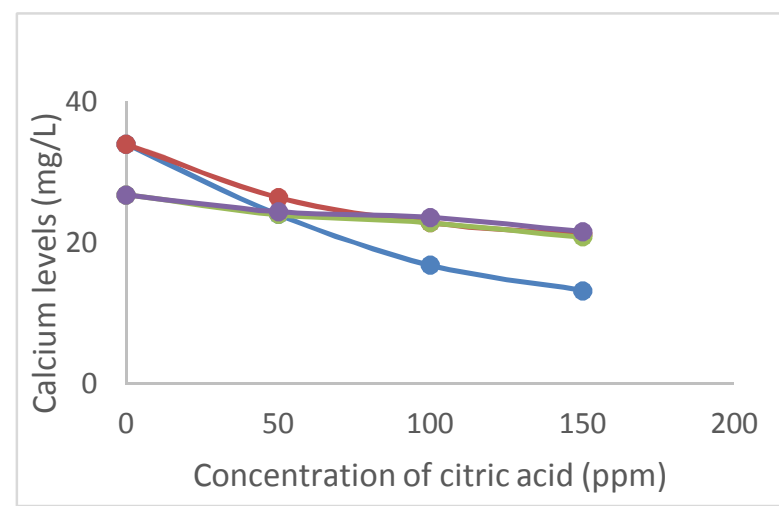

Figure 2. Water calcium levels in the tondo and tipo regions ( $\bullet$ is commercial citric acid-Tondo; $\bullet$ is a citric acid extract-Tondo; is commercial citric acid-Tipo; is commercial citric acid extract-Tipo).

From the results obtained, it can be seen that the decrease in calcium levels increases with increasing the concentration of citric acid used. This is confirmed by the research of Ekholm et al. (2000), which states that citric acid is the most efficient chelating agent for $\mathrm{Ca}, \mathrm{Zn}, \mathrm{Mg}$, and $\mathrm{Mn}$ metals. The higher the concentration of citric acid, the more the intensity of proton nesting against the mineral bonds so that the number of protons that may be released also increases. This causes more and more metals to be bound by citrate ions.

In determining the level of calcium for water in the Tondo area, there was a significant difference between the addition of commercial citric acid and the addition of extracted citric acid. This occurs presumably because the extracted citric acid is not yet in a pure state, and it is also difficult to observe the color change that occurs; as a result, the determination of the endpoint of the titration is less accurate.

The results of the study for Tipo regional water also showed that the use of commercial citric acid and extracted citric acid did not show a significant difference. This happened presumably because the metal ions contained in the Tipo Village area were less than the metal ions found in the water in the Tondo Village area, so that the results obtained were almost the same.

\section{Determination of Magnesium Levels}

The decrease in the total hardness levels of Tondo water and Tipo water can be seen in Figure 3.

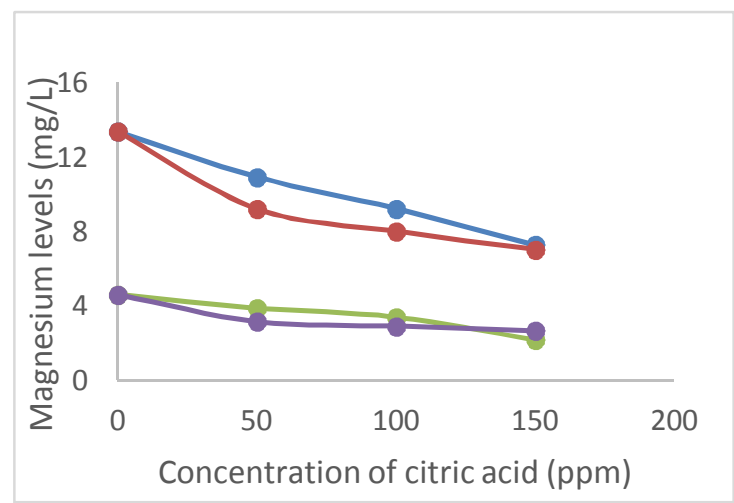

Figure 3. Water magnesium levels in the tondo and tipo regions ( $\bullet$ is commercial citric acid-Tondo; $\bullet$ is a citric acid extract-Tondo;

$\checkmark$ is commercial citric acid-Tipo; $\bullet$ is commercial citric acid extract-Tipo) 
The magnesium content in the water of the Tondo Village area is caused by the presence of granite rocks containing biotite minerals and gypsum, which contains magnesium. The decrease in magnesium content with the addition of commercial citric acid occurs regularly so that it forms a straight line on the graph. In contrast to the addition of commercial citric acid, the decrease in magnesium content with the addition of citric acid extracted was irregular but greater than the addition of commercial citric acid. This occurs presumably because the extracted citric acid is still in an impure state so that the magnesium is bound to other compounds contained in the extract as well as the influence of other metal ions on the determination of magnesium content.

The Tipo area has sandstone containing mica minerals $\left((\mathrm{K}, \mathrm{Na}, \mathrm{Ca})(\mathrm{Mg}, \mathrm{Fe}, \mathrm{Li}, \mathrm{Al}) 2-3(\mathrm{Al}, \mathrm{Si})_{4}\right.$ $\left.\mathrm{O}_{2}(\mathrm{OH}, \mathrm{F})_{2}\right)$ so that the water in the Tondo area contains magnesium. Magnesium is one of the elements that play a role in water hardness. The results obtained indicate that there is a difference between the use of extracted citric acid and the use of commercial citric acid. The citric acid extracted gave a greater reduction at the concentration of 50 ppm and $100 \mathrm{ppm}$, while the addition of citric acid at a concentration of $150 \mathrm{ppm}$, the decrease in magnesium levels was greater with the addition of citric acid. This occurs presumably because the extracted citric acid is not yet in a pure state, and it is also difficult to observe the color change that occurs; as a result, the determination of the endpoint of the titration is less accurate, and the content of other metal ions in the water which can interfere with the determination of magnesium levels.

\section{Acknowledgment}

The author's gratitude goes to the laboratory assistant for Chemical Education, Faculty of Teacher Training and Education, the University of Tadulako, who helped the author a lot in completing this research.

\section{References}

Ahmad, L. A., Kusumastuti, A., Buddin, S. H. M. M., Derek, C. J. C., \& Seng, B. O. (2014). Emulsion liquid membrane based on a new flow pattern in a counter rotating taylor-couette column for cadmium extraction. Separation and Purification Technology, 12(7), 46-52.

Apriliani, F, N., Baqiya, A. M., \& Darminto. (2012). Pengaruh penambahan larutan $\mathrm{MgCl}_{2}$ pada sintesis kalsium karbonat presipitat berbahan dasar batu kapur dengan metode karbonasi. Jurnal Sains dan Seni Institut Teknologi Sepuluh November, 1(1), 30-34.

Bizri, J. N., \& Wahem, I. A. (1994). Citric acid and antimicrobials affect microbiological stability and quality of tomato juice. Journal of Food Science, 59(1), 130-134.
Butryee, C., Sungpuang, P., \& Chitchumroonchockhai, C. (2009). Effect of processing on the flavonoid content and antioxidant capacity of citrus hystrix leaf. International Journal of Food Sciences and Nutrition. 60(2), 162-174.

Chen, Y. X., Lin, Q., Luo, Y. M., He, Y. F., Zhen, S. J., Yu, Y. L., Tian, G. M., \& Wong, M. H. (2003). The role of citric acid on the phytoremediation of heavy metal contaminated. Chemosphere, 50(6), 807-811.

Ekholm, P., Virkki, L., Ylinen, M., Johansson, L., $\&$ Varo, P. (2000). Effects of natural chelating agents on the solubility of some physiologically important mineral element in oat bran and oat flakes. Cereal Chemistry, 77(5), 562-566.

Harsanti, D. (2010). Sintesis dan karakterisasi boron karbida dari asam borat, asam sitrat dan karbon aktif. Jurnal Sains \& Teknologi Modifikasi Cuaca, 11(1), 29-40.

Herjuna, S. (2011). Pemanfaatan bahan humat dan abu terbang untuk reklamasi lahan bekas tambang. Tesis Tidak Diterbitkan. Bogor: Institut Pertanian Bogor.

Haq, I. G., Permanasari, A., \& Sholihin, H. (2010). Efektivitas penggunaan sari buah jeruk nipis terhadap ketahanan nasi. Jurnal Sains dan Teknologi Kimia, 1(1), 44-58.

Joko, S. (2010). Bertani jeruk purut. Yogyakarta: Pustaka Baru Press

Kusnaedi. (2010). mengolah air kotor untuk air minum. Jakarta: Swadaya.

Labanu, R. S., H. Iqbal \& Farhamsa. D. (2015). Proyeksi pemetaan sebaran kesadahan air tanah di Kota Palu berbasis web menggunakan aplikasi google Maps API. Gravitasi, 14(1), 6067.

Marsidi, R. (2001). Zeolit untuk mengurangi kesadahan air. Jurnal Teknologi Lingkungan, 2(1), 1-10.

Munawaroh, S., \& Handayani, P. A. (2010). Ekstraksi minyak daun jeruk purut (citrus hystrix d.c.) dengan pelarut etanol dan nheksana. Jurnal Kompetensi Teknik, 2(1), 73-78.

Ngadenin., Syaeful, H., Widana, K. S., Sukadana, I. G., \& Indrastomo, D. Fd. (2014). Studi potensi thorium pada batuan granit di Pulau Bangka. Jurnal Pengembangan Energi Nuklir, 16(2), 143-155.

Gomes, M. (1996). Fighting disease, fostering development: the report of the director-general: World Health Organization.

Pratiwi, F., Istiqoma., A., Prakasa, W., \& Tinata, K. J. (2015). Ekstraksi asam sitrat dalam kulit jeruk sebagai bahan pemutih pada pasta gigi. Diakses 20 Januari 2019, dari http://bima.dinus.ac.id/dokumen/_ekstraksi_ asam_sitrat_dalam_ku.pdf. 
Septiana, A., Arienata, F., \& Kumoro, A. C. (2013). Potensi jus jeruk nipis (citrus aurantifolia) sebagai bahan penghelat dalam proses pemurnian minyak nilam (patchouli oil) dengan metode kompleksometri. Jurnal Teknologi Kimia dan Industri. 1(1), 21-28.

Setiawan, S. T., Rachmadiarti, F., \& Raharjo. (2012). The Effectiveness of Various Types of orange (Citrus Sp.) to the Reduction of $\mathrm{Pb}$ (Lead) and $\mathrm{Cd}$ (Cadmium) heavy metals concentration on white shrimp (Penaeus Marguiensis). LenteraBio, 1(1), 35-40.

Siregar, A. D. (2010). Pemanfaatan gipsum karangnunggal kabupaten tasikmalaya untuk pembuatan papan gipsum. Jurnal Teknologi Mineral dan Batubara, 6(2), 92-99.

Standar Nasional Indonesia (SNI). (2004). Air dan limbah bagian 12: cara uji kesadahan kalsium
(Ca) dan magnesium ( $\mathrm{Mg}$ ) dengan metode titrimetri. Diakses 12 Februari 2019, dari Website Pusat Standarisasi Lingkungan dan Kehutanan:

http://standardisasi.menlhk.go.id/index.php/d aftar-standar-nasional/sni/teknologipengujian/kualitas-air-dan-air-limbah/,

Sutrisno, T., \& Suciastuti, E. (2002). Teknologi penyedian air bersih. Jakarta: Rineka Cipta.

Srisukh, V., C., Tribuddharat, V., Nukoolkarn, N., Bunyapraphatsara, K., Chokephaibulkit, S., Phoomniyom, S., Chuanpung., \& Srifuengfung, S. (2012). Antibacterial activity of essential oils from citrus hystrix (makrut lime) against respiratory tract pathogens. ScienceAsia, 38, 212-217. 